\section{Nutritional factors associated with chronic non- communicable diseases - the Bambuí Project: a population-based study}

\author{
Fatores nutricionais associados com doenças \\ crônicas não transmissíveis - Projeto Bambuí: \\ estudo de base populacional
}

\author{
${ }^{1}$ Escola de Enfermagem, \\ Universidade Federal de \\ Minas Gerais, Belo Horizonte, \\ Brasil. \\ 2 Núcleo de Estudos \\ em Saúde Pública e \\ Envelhecimento, Fundação \\ Oswaldo Cruz/Universidade \\ Federal de Minas Gerais, Belo \\ Horizonte, Brasil. \\ 3 Faculdade de Medicina, \\ Universidade Federal de \\ Minas Gerais, Belo Horizonte, \\ Brasil. \\ Correspondence \\ A. C. S. Lopes \\ Departamento de Enfermagem \\ Materno-Infantil e \\ Saúde Pública, Escola de \\ Enfermagem, Universidade \\ Federal de Minas Gerais \\ Av. Bernardo Vasconcelos 2550, \\ apto. 508, Belo Horizonte, \\ MG 31160-440, Brasil. \\ aline@enf.ufmg.br
}

\section{Abstract}

The increase of chronic non-communicable diseases has been significant. The objective of this study was to identify factors related to food intake, anthropometry and biochemical measurements associated with chronic non-communicable diseases. It involved a cross-sectional study among a representative sample of adults and elderly people in Bambuí, Minas Gerais State, Brazil. Anthropometric, biochemical and nutrient intake data were evaluated. The study included 409 individuals (55.3\% of whom were women), with a mean age of $40.6 \pm 16.0$ years. There was found to be a $14 \%$ rate of obesity associated with high/very high triglycerides and arterial hypertension. Arterial hypertension was present in $22.4 \%$ of subjects and correlated with age $>60$ years, insufficient protein intake, obesity and high cholesterol. Diabetes was found in $3.7 \%$ and was associated with large waist circumference, excessive saturated fatty acids and arterial hypertension. The factors associated with chronic non-communicable diseases were obesity, high total cholesterol, triglycerides and excessive consumption of saturated fatty acids. The identification of the nutritional factors associated with chronic non-communicable diseases can support future interventions.

Food Consumption; Anthropometry; Biological Markers; Chronic Disease
Aline Cristine Souza Lopes 1 Luana Caroline dos Santos 1 Maria Fernanda Lima-Costa 2 Waleska Teixeira Caiaffa ${ }^{3}$

\section{Introduction}

The epidemiological transition is characterized by an increase in mortality rates related to noncommunicable diseases and decreased rates of communicable diseases 1 , while the nutritional transition is characterized by changes in dietary habits and increased obesity ${ }^{2}$. The demographic transition is characterized by accelerated population aging and globalization is characterized by the rapid spreading of habits and behavioral patterns ${ }^{3}$. These changes have given rise to different lifestyles and health profiles among populations. According to the World Health Organization (WHO), chronic non-communicable diseases were responsible for $60 \%$ of the 56.5 million deaths around the world in the year 2001, and accounted for $46 \%$ of the overall disease burden. In Brazil, chronic non-communicable diseases were responsible for $55.2 \%$ of deaths and $58 \%$ of years of life lost due to premature death 4 .

Specifically in relation to systemic arterial hypertension, according to the Risk and Protection Factors Surveillance System for Chronic Non-Communicable Diseases Through Telephone Interview (VIGITEL), $24.4 \%$ of Brazilians (over the age of 18) reported the presence of this disease 5. In Brazil between July 2000 and June 2001 , there were $1,143,955$ hospitalizations due to cardiovascular disease $(9.7 \%$ of the total). Of these, $14.9 \%$ related to systematic arterial hypertension, $11 \%$ to cerebrovascular diseases and 
$5.5 \%$ to ischemic heart diseases, and the latter two were both associated with systematic arterial hypertension 6 .

This trend of an increase in the incidence of chronic non-communicable diseases must be considered in the context of increased obesity. According to the National Health and Nutrition Survey (PNSN 1990), 24.6\% of the population presented overweight and $8.3 \%$ presented obesity, while in the Brazilian Household Budget Survey (POF 2008/2009) 7, the prevalences were 34.2\% and $14.8 \%$, respectively, and in VIGITEL, $32.7 \%$ and $13.9 \% 5$.

Increased obesity is strongly related to changes in dietary patterns. Present food intake trends among the Brazilian population, according to the POF surveys of 1987, 1996 and 2003, reveal increasing fat (particularly animal fat) and sugar intake, accompanied by reductions in the intake of cereals, fruits, leguminous vegetables, greens and other vegetables. Thus, the diet is increasingly poor in vitamins and minerals. Furthermore, the increasing frequency of consumption of manufactured foods and meals outside of the home can be highlighted 7 .

In light of this new nutritional and epidemiological pattern, it has become necessary to investigate the nutritional factors relating to occurrences of chronic non-communicable diseases, with an emphasis on obesity, systematic arterial hypertension and diabetes. Therefore, this article had the aim of identifying the factors relating to food intake, anthropometry and biochemical measurements that were associated with these diseases among adults and elderly people living in Bambuí, Minas Gerais State, Brazil.

\section{Materials and methods}

The Bambuí Project is a population-based epidemiological study developed in Bambuí, a municipality with around 15,000 inhabitants.

\section{Sample}

The sample for this dietary survey consisted of 660 individuals who were selected randomly. The assumptions made in determining the sample size were $2.5 \%$ sample error, $20 \%$ prevalence of excess weight, $95 \%$ confidence interval and $20 \%$ losses.

There were 550 respondents in this survey (83.2\%), among which anthropometric, biochemical and food intake information was available for 409 individuals (62\%). It is important to point out that, despite the sample loss, there were no significant differences in age distribution and sex.

\section{Type of study and data collection}

A cross-sectional study was carried out in 19961997. Demographic, anthropometric and food intake information was collected and biochemical assays were performed, as described below.

The demographic data such as sex and age were obtained by means of a face-to-face questionnaire.

The anthropometric measurements were standardized in accordance with techniques used worldwide 8 . Each parameter was measured three times and the mean was used. The body mass index (BMI) was calculated from the weight and height measurements and the waist-hip ratio (WHR) was calculated from the waist circumference (WC) and hip circumference (HC).

The nutritional status was classified from the BMI according to age, for adults (18-59 years) 8 and elderly people ( $\geq 60$ years) 9 . The reference values for WHR and the WC were the values proposed by the WHO 8 .

Diabetes was defined as a fasting glucose level of $126 \mathrm{mg} / \mathrm{dL}$ or more, or if the subject reported current use of insulin or oral hypoglycemic agents. And hypertension was defined as blood pressure $\geq 140 / 90 \mathrm{mmHg}$ and/or current use of hypotensive drugs 10 .

The nutrient information was obtained by calibration between two dietary methods: the Semiquantitative Food Frequency Questionnaire (SQFFQ) and the 24-hour recall associated with food responses (24R) 11.

The biochemical measurements of total cholesterol, HDL-cholesterol, triglycerides and glycemia were obtained after a 12-hour fast, using automated equipment (Eclipse Vitalab, Merck, Netherlands). The reference values for adequate lipid levels were the values proposed by the Third Brazilian Guidelines for Dyslipidemia and the Guidelines for Atherosclerosis Prevention 12, and for glycemia, the Diabetes Guidelines of the Brazilian Diabetes Society 13.

The Bambuí Project was approved by the Ethics Committee of the Oswaldo Cruz Foundation, and all the participants signed a free and informed consent statement.

\section{Statistical analysis}

The information from the SQFFQ was transformed into nutrient values using a software application developed within SPSS 11.0 for Windows (SPSS Inc., Chicago, USA). The food composition database was constructed from the $\mathrm{Nu}$ - 
trition Support software, version 2.5 (Centro de Informática em Saúde, Escola Paulista de Medicina, Universidade Federal de São Paulo, São Paulo, Brazil), and from food composition tables.

Descriptive analysis was performed on the data and chi-squared and Fisher exact tests were applied. Univariate and multivariate Poisson regression analyses were used, with a stepwise criterion for variable selection.

\section{Results}

The study sample was composed of 409 individuals, of whom $55.3 \%(n=226)$ were female. The mean age was $40.6 \pm 16.0$ years, and $13.7 \%$ $(n=56)$ of the subjects were classified as elderly ( $\geq 60$ years).

The prevalences of nutritional deviations were that $6.1 \%$ of the subjects were underweight, $30.2 \%$ were overweight and $14 \%$ were obese. The women presented higher frequencies of underweight ( $8 \%$ vs. $3.8 \%$ : $p<0.01)$ and obesity $(18.2 \%$ vs. $8.8 \%$ : $\mathrm{p}<0.01)$.

Insufficient protein and vitamin $\mathrm{B}_{6}$ intake was observed in $59.7 \%$ and $50.1 \%$, respectively, with significant differences between the sexes and age groups. The percentages of individuals with excessive consumption of lipids (29.6\%), phosphorus (69.2\%) and saturated fatty acids (22.5\%) were high. Abnormal cholesterol, HDL and triglyceride concentrations were also found in a large proportion of the sample (Table 1).

Among the participants, systematic arterial hypertension and diabetes were identified in $22.4 \%$ and $3.7 \%$, respectively. Systematic arterial hypertension was more frequent among women ( $26.6 \%$ vs. $17.2 \%$ in men; $\mathrm{p}=0.03$ ) and the elderly ( $60 \%$ vs. $17 \%$ in adults; $\mathrm{p}<0.01$ ). Diabetes was more frequent only among the elderly ( $14 \%$ vs. $2.3 \% ; \mathrm{p}=0.001$ ).

Obesity was positively associated with female sex, inadequacy of protein and phosphorus intake, large WC, diminished glucose tolerance, diabetes, systematic arterial hypertension and high triglyceride levels (Table 2). In the multivariate analysis, presence of systematic arterial hypertension and high levels of triglycerides remained associated with obesity. The anthropometric variables were disregarded because of the high correlation between them (Table 3).

The factors associated with occurrences of systematic arterial hypertension were age $(\geq 60$ years), insufficient protein, phosphorus and vitamin $\mathrm{B}_{6}$ intake, low polyunsaturated-to-saturated fatty acid ratio, obesity, large WC, high WHR, diminished glucose tolerance, diabetes, high cholesterol and high triglycerides (Table 2). Among these, age, insufficient protein intake, high cholesterol, obesity and diabetes remained associated (Table 3).

In univariate analysis, age classification, excessive fatty acid intake, high triglycerides and systematic arterial hypertension, along with large WC and high WHR, were significantly associated with diabetes (Table 2). Large WC, excessive fatty acid intake and systematic arterial hypertension were associated in the multivariate analysis (Table 3).

\section{Discussion}

High occurrence rates of nutritional deviations were found in the present study, particularly excess weight, abnormalities of serum lipid levels and inadequate nutrient intake. These factors may contribute towards the occurrence of chronic non-communicable diseases, especially among women and elderly people, who make up the groups most susceptible to these diseases 2,3 .

The association found between systematic arterial hypertension, high triglycerides and obesity should be thought of as a possible limitation to the study, consequent to the design used. In cross-sectional studies, no temporality is determined and it is therefore possible to identify associations of factors that are consequences or intermediate stages of the disease, i.e. prevalence study bias, such as the presence of systematic arterial hypertension and high triglycerides associated with obesity. Future analyses of cohorts might overcome this limitation.

Furthermore, other biologically plausible factors need to be considered. Even though the insufficiency of calcium and fiber intake was non-significant, it may have been important because almost $100 \%$ of the subjects presented low intake, thus possibly contributing towards occurrences of obesity 2 .

However, the trio of obesity, systematic arterial hypertension and high triglycerides brings a notable increase in the cardiovascular risk. Within this context, good nutrition associated with practicing physical exercise is capable of ensuring good health for individuals 1 .

Among the factors associated with occurrences of systematic arterial hypertension, old age was prominent: it roughly doubled the chance of being hypertensive, probably because of physiological changes during aging that favor the occurrence of systematic arterial hypertension, such as hydroelectrolytic imbalance, vascular changes and body composition changes 3,14. A study conducted in Pelotas, Rio Grande do Sul State 14, with a representative 
Table 1

Prevalence of adequate nutritional status, considering anthropometry, nutrient intake and biochemical parameters according to sex and age group. Bambuí, Minas Gerais State, Brazil, 1996-1997.

\begin{tabular}{|c|c|c|c|c|c|c|c|}
\hline Adequacy & $\begin{array}{l}\text { Whole sample } \\
\qquad(n=409)\end{array}$ & $\begin{array}{c}\text { Men } \\
(n=182)\end{array}$ & $\begin{array}{l}\text { Women } \\
(n=225)\end{array}$ & p-value * & $\begin{array}{c}\text { Adults } \\
(n=352)\end{array}$ & $\begin{array}{l}\text { Elderly } \\
\text { people } \\
(n=56)\end{array}$ & p-value ** \\
\hline Large WC *** & 13.2 & 12.6 & 13.7 & 0.34 & 11.6 & 23.2 & $<0.01$ \\
\hline Very large WC & 5.5 & 7.7 & 3.7 & 0.20 & 4.6 & 10.7 & 0.03 \\
\hline High waist/hip ratio & 19.2 & 1.1 & 34.1 & $<0.01$ & 14.7 & 46.4 & $<0.01$ \\
\hline Insufficient protein & 21.8 & 16.4 & 26.1 & $<0.01$ & 15.6 & 60.7 & 0.03 \\
\hline Excessive protein & 59.7 & 56.3 & 62.4 & 0.02 & 66.6 & 16.1 & $<0.01$ \\
\hline Excessive lipids & 29.6 & 30.6 & 28.8 & 0.41 & 28.0 & 39.3 & $<0.01$ \\
\hline Insufficient phosphorus & 9.5 & 4.4 & 13.7 & $<0.01$ & 8.8 & 14.3 & $<0.01$ \\
\hline Excessive phosphorus & 69.2 & 80.3 & 60.2 & 0.51 & 68.0 & 76.8 & $<0.01$ \\
\hline Insufficient vitamin $\mathrm{B}_{6}$ & 50.1 & 40.4 & 58.0 & $<0.01$ & 48.7 & 58.9 & $<0.01$ \\
\hline Excessive vitamin $B_{6}$ & 11.7 & 17.5 & 7.1 & 0.02 & 12.2 & 8.9 & $<0.01$ \\
\hline Excessive saturated fatty acids \# & 22.5 & 22.4 & 22.6 & 0.29 & 20.1 & 37.5 & $<0.01$ \\
\hline Insufficient $\mathrm{P} / \mathrm{S}$ ratio \#\# & 30.3 & 26.2 & 33.6 & 0.01 & 28.6 & 41.1 & $<0.01$ \\
\hline Threshold cholesterol \#\#\# & 24.8 & 25.3 & 24.3 & 0.37 & 23.3 & 33.9 & $<0.01$ \\
\hline High cholesterol § & 13.7 & 11.0 & 15.9 & 0.03 & 10.8 & 32.1 & $<0.01$ \\
\hline Low HDL-cholesterol §§ & 20.3 & 27.5 & 14.6 & 0.06 & 19.0 & 28.6 & $<0.01$ \\
\hline Threshold triglycerides §§§ & 12.5 & 10.4 & 14.2 & 0.07 & 15.9 & 21.4 & $<0.01$ \\
\hline High/very high triglycerides $†$ & 18.8 & 20.8 & 17.3 & 0.91 & 16.5 & 33.9 & $<0.01$ \\
\hline
\end{tabular}

P/S: polyunsaturated fatty acids/saturated fatty acids; WC: waist circumference.

* Test comparing proportions between the sexes;

** Test comparing proportions between adults and elderly people;

$\star \star \star$ Waist circumference;

\# Saturated fatty acid;

\#\# Polyunsaturated/Saturated;

\#\#\# Threshold cholesterol (200-239mg/dL);

$\S$ High cholesterol $(\geq 240 \mathrm{mg} / \mathrm{dL})$;

$\S \S$ low HDL $(<40 \mathrm{mg} / \mathrm{dL}$ );

$\S \S \S$ Threshold triglycerides (150-200mg/dL);

† High/very high triglycerides ( $\geq 201 \mathrm{mg} / \mathrm{dL}$ ).

sample of the population also found a greater frequency of systematic arterial hypertension among elderly people (prevalence ratio $=9.54$; 95\% confidence interval - 95\%CI: 6.32-14.39).

Another factor associated with systematic arterial hypertension was insufficient protein intake. It can be emphasized that individuals who present this inadequacy, in relation to other subjects, had lower calcium intake, low polyunsaturated fatty acid intake and greater age, BMI and blood cholesterol ( $\mathrm{p}<0.05)$. These factors may raise pressure levels 7,15 .

The occurrence of diabetes was associated with excessive intake of fatty acids, abdominal obesity and systematic arterial hypertension, thus corroborating other studies 6,7,16,17. Lipid quality has an important role in the risk of developing diabetes. A positive correlation between saturated fat intake and glycemia levels has been demonstrated, with greater risk of progression from diminished glucose tolerance to diabetes 13,16 .

Furthermore, excess weight, especially abdominal, has been associated with the risk of developing diabetes, diminished glucose tolerance and other chronic non-communicable diseases. This relationship is due to an increased release of non-esterified fatty acids into the circulation, which is promoted by abdominal fat. In addition, there is an increased release of adipocytokines, such as tumor necrosis factor and interleukin-6, which is associated with reductions in adiponectin and imbalances of other hormones (leptin and ghrelin, for example), and may negatively 


\section{Table 2}

Univariate Poisson regression analyses (prevalence ratio - PR and 95\% confidence interval - 95\%Cl) for nutritional diagnoses of obesity, hypertension and diabetes. Bambuí, Minas Gerais State, Brazil, 1996-1997.

\begin{tabular}{|c|c|c|c|}
\hline \multirow[t]{2}{*}{ Variables } & \multicolumn{3}{|c|}{ PR $(95 \% \mathrm{Cl})$} \\
\hline & Obesity & Arterial hypertension & Diabetes \\
\hline Age $\geq 60$ years & * & $3.52(2.27-5.46)$ & $6.14(2.23-16.94)$ \\
\hline Female sex & $2.07(1.16-3.69)$ & * & * \\
\hline Insufficient protein & $2.08(1.22-3.57)$ & $3.52(2.33-5.31)$ & * \\
\hline Insufficient phosphorus & $2.01(1.02-3.97)$ & $1.86(1.07-3.24)$ & * \\
\hline Insufficient vitamin $B_{6}$ & * & $1.90(1.23-2.94)$ & * \\
\hline Excessive saturated fatty acids $\star \star$ & * & * & $3.07(1.11-8.46)$ \\
\hline Insufficient $\mathrm{P} / \mathrm{S}$ ratio *** & * & $1.62(1.07-2.47)$ & * \\
\hline Obesity & $\#$ & $2.63(1.68-4.13)$ & $5.36(1.94-14.78)$ \\
\hline Large WC \#\# & $12.42(6.76-22.83)$ & $2.31(1.50-3.57)$ & $6.58(2.34-18.47)$ \\
\hline High WHR \#\# & $3.78(2.23-6.43)$ & $3.22(2.12-4.90)$ & $6.60(2.35-18.53)$ \\
\hline Diminished glucose tolerance & $2.23(1.28-3.89)$ & $2.41(1.56-3.75)$ & $\#$ \\
\hline Diabetes & $3.66(1.66-8.07)$ & $3.58(1.91-6.73)$ & $\#$ \\
\hline Arterial hypertension & $3.21(1.90-5.42)$ & $\#$ & $9.50(3.03-29.84)$ \\
\hline High cholesterol & * & $2.99(1.92-4.65)$ & * \\
\hline Threshold triglycerides & * & $2.19(1.25-3.84)$ & * \\
\hline High/very high triglycerides & $2.31(1.34-3.98)$ & $2.61(1.64-4.16)$ & $3.87(1.40-10.66)$ \\
\hline
\end{tabular}

P/S: polyunsaturated fatty acids/saturated fatty acids.

* Non-significant prevalence ratios;

** Saturated fatty acid;

*** Polyunsaturated/Saturated;

\# Calculation does not apply;

\#\# Waist circumference;

\#\#\# Waist/hip ratio.

Table 3

Multivariate Poisson regression analysis for the outcomes of obesity, hypertension and diabetes. Bambuí, Minas Gerais State, Brazil, 1996-1997.

\begin{tabular}{|c|c|c|c|}
\hline Equation parameters & Obesity & $\begin{array}{l}\text { Systemic arterial } \\
\text { hypertension }\end{array}$ & Diabetes \\
\hline \multirow[t]{5}{*}{$\begin{array}{l}\text { Variables } \\
\text { (coefficient; PR; 95\% } \mathrm{Cl} \text { ) }\end{array}$} & $\begin{array}{c}\text { Systematic arterial } \\
\text { hypertension } \\
(2.47 ; 1.43-4.27)\end{array}$ & Age $\geq 60(1.65 ; 1.01-2.72)$ & $\begin{array}{l}\text { Large waist circumference } \\
\qquad(4.06 ; 1.40-11.74)\end{array}$ \\
\hline & $\begin{array}{l}\text { High/very high triglycerides } \\
\qquad(2.37 ; 1.26-4.45)\end{array}$ & $\begin{array}{l}\text { Insufficient protein } \\
(2.36 ; 1.50-3.71)\end{array}$ & $\begin{array}{l}\text { Excessive saturated fatty } \\
\text { acids }(2.82 ; 1.02-7.76)\end{array}$ \\
\hline & & $\begin{array}{l}\text { High cholesterol } \\
(1.95 ; 1.22-3.10)\end{array}$ & $\begin{array}{c}\text { Systematic arterial } \\
\text { hypertension } \\
(6.33 ; 1.95-20.51)\end{array}$ \\
\hline & & Diabetes $(2.20 ; 1.10-4.43)$ & \\
\hline & & Obesity $(1.81 ; 1.12-2.92)$ & \\
\hline
\end{tabular}

PR: prevalence ratio; $95 \% \mathrm{Cl}$ : 95\% confidence interval. 
affect insulin sensitivity and favor the development of chronic non-communicable diseases 16 .

In analyzing the association with systematic arterial hypertension, it was not possible to identify the importance of sodium intake, and it is recommended that this should be analyzed in subsequent studies. With regard to occurrences of obesity, methodological limitations such as inadequate dietary profiles were found both among obese and among eutrophic individuals. It is recommended that other factors associated with excess weight, such as physical activity levels should be better investigated.

\section{Resumo}

É expressivo o aumento da ocorrência de doenças e agravos não transmissíveis. Identificar fatores referentes ao consumo alimentar, antropometria e medidas bioquímicas associados às doenças e agravos não transmissíveis em Bambuí, Minas Gerais, Brasil. Estudo transversal com amostra representativa de adultos e idosos de Bambuí. Foram avaliados dados antropométricos, bioquímicos e consumo de nutrientes. Participaram 409 indivíduos, 55,3\% mulheres, com idade média de 40,6 $\pm 16,0$ anos. Verificaram-se $14 \%$ de obesidade associada ao triglicerídeos alto/muito alto e hipertensão arterial. Hipertensão arterial esteve presente em $22,4 \%$ e relacionou-se à idade $>60$ anos, consumo insuficiente de proteínas, obesidade e colesterol elevado. Identificou-se diabetes em 3,7\% da amostra associada à circunferência da cintura elevada, ácidos graxos saturados excessivo e hipertensão arterial. Os fatores associados às doenças e agravos não transmissiveis investigados foram obesidade, elevação do colesterol total, triglicerídeos e consumo excessivo de ácidos graxos saturados. A identificação destes fatores associados à ocorrência das doenças e agravos não transmissíveis poderá subsidiar futuras intervenções.

Consumo de Alimentos; Antropometria; Marcadores Biológicos; Doença Crônica
It is concluded that identification of nutritional factors associated with occurrences of chronic diseases may form a strategy for defining interventions for modifiable factors. Abdominal and overall obesity, along with high total cholesterol and triglycerides and excessive intake of saturated fatty acids, were shown to be factors in this group for which interventions were possible. Such actions could significantly reduce occurrences of obesity, systematic arterial hypertension and diabetes, which have notable impacts on quality of life.

\section{Contributors}

All the authors participated in writing the article, critically reviewing the intellectual content and approving the final version. 


\section{References}

1. Amuna P, Zotor FB. Epidemiological and nutrition transition in developing countries: impact on human health and development. Proc Nutr Soc 2008; 67:82-90.

2. Astrup A, Dyerberg J, Selleck M, Stender S. Nutrition transition and its relationship to the development of obesity and related chronic diseases. Obes Rev 2008; 9 Suppl 1:48-52.

3. Lunenfeld B. An aging world-demographics and challenges. Gynecol Endocrinol 2008; 24:1-3.

4. Instituto Nacional de Câncer. Inquérito domiciliar sobre comportamento de risco e morbidade referida de doenças e agravos não-transmissíveis: Brasil, 15 capitais e Distrito Federal, 2002-2003. Rio de Janeiro: Instituto Nacional de Câncer; 2004.

5. Secretária de Vigilância em Saúde, Secretaria de Gestão Estratégica e Participativa. VIGITEL 2009: Vigilância de fatores de risco e proteção para doenças crônicas por inquérito telefônico. Brasília: Ministério da Sáude; 2010.

6. Machado CA. Epidemiologia da Hipertensão e classificação da pressão arterial. São Paulo: Sociedade Brasileira de Hipertensão; 2005. http://www. itarget.com.br/clients/sbh.org.br/sbh_profissio nais (accessed on 10/Jul/2007).

7. Instituto Brasileiro de Geografia e Estatística. Pesquisa de Orçamento Familiar (POF) 2008-2009: antropometria e estado nutricional de crianças, adolescentes e adultos no Brasil. Rio de Janeiro: Instituto Brasileiro de Geografia e Estatística; 2010.

8. World Health Organization. Consultation on obesity. Defining the problem of overweight and obesity. In: Akram DS, Asturp AV, Atinmo T, Boissin JL, Bray GA, Carroll KK, editors. Preventing and managing the global epidemic. Geneva: World Health Organization; 1997. (Report of a WHO Consultation on Obesity).
9. Lipschitz DA. Screening for nutritional status in the elderly. Prim Care 1994; 21:55-67.

10. Passos VMA, Barreto SM, Diniz LM, Lima-Costa MF. Type 2 diabetes: prevalence and associated factors in a Brazilian community - the Bambuí health and aging study. São Paulo Med J 2005; 123:66-71.

11. Lopes ACS, Caiaffa WT, Mingoti SA, Sichieri R, Lima-Costa MF. Consumo de nutrientes em adultos e idosos em estudo de base populacional: Projeto Bambuí. Cad Saúde Pública 2005; 21:1201-9.

12. Santos RD; Sociedade Brasileira de Cardiologia. III Diretrizes Brasileiras sobre Dislipidemia e Diretriz de Prevenção da Aterosclerose. Arq Bras Cardiol 2001; 77 Suppl 3:1-48.

13. Sociedade Brasileira de Diabetes. Tratamento e acompanhamento do diabetes mellitus: diretrizes da Sociedade Brasileira de Diabetes. Rio de Janeiro: Diagraphic Editora; 2007.

14. Taddei S, Virdis A, Ghiadoni L, Versari D, Salvetti A. Endothelium, aging, and hypertension. Curr Hypertens Rep 2006; 8:84-9.

15. Costa JS, Barcellos FC, Sclowitz ML, Sclowitz IK, Castanheira M, Olinto MT, et al. Hypertension prevalence and its associated risk factors in adults: a population-based study in Pelotas. Arq Bras Cardiol 2007; 88:59-65.

16. Sartorelli DS, Franco LJ. Tendências do diabetes mellitus no Brasil: o papel da transição nutricional. Cad Saúde Pública 2003; 19 Suppl 1:S29-36.

17. Franz MJ, Powers MA, Leontos C, Holzmeister LA, Kulkarni K, Monk A, et al. The evidence for medical nutrition therapy for type 1 and type 2 diabetes in adults. J Am Diet Assoc 2010; 110:1852-89.

Submitted on 27/Aug/2010

Final version resubmitted on 31/Jan/2011

Approved on 22/Feb/2011 